[Radiocarbon, Vol 22, No. 2, 1980, P 556-561]

\title{
RADIOCARBON AGES OF SHELLS IN HOLOCENE MARINE DEPOSITS
}

\author{
JOAKIM DONNER and HÖGNE JUNGNER \\ Radiocarbon Dating Laboratory, University of Helsinki, Finland
}

\begin{abstract}
Radiocarbon dates of marine shells from Central West Greenland, Finnmark, in North Norway, and Dublin Bay, in Ireland, were used in dating relative sea-level changes. When fossil assemblages and formation of marine deposits and their 1elationship to sea-level were taken into account, the constructed curves of relative sea-level changes agreed with the shell dates. The origin of the shells in the deposits studied varied from site to site, but the dates gave additional information of the formation of marine deposits which could not have been obtained from the study of sediments alone.
\end{abstract}

\section{INTRODUCTION}

Since 1972 the Radiocarbon Dating Laboratory of the University of Helsinki has dated 58 samples of Holocene marine shells from deposits above the present sea-level in the Disko Bugt area (Donner and Jungner, 1975) and on the west coast of Disko (Donner, 1978) in Central West Greenland, in Finnmark, North Norway (Donner, Eronen, and Jungner, 1977; see also, Donner and Jungner, 1979), and north of Dublin Bay in Ireland. Eighty percent of the innermost part of the shell samples were used and the dates were based on the half-life of $5568 \pm 30$ years for ${ }^{14} \mathrm{C}$. No corrections based on $\delta^{13} \mathrm{C}$ values or apparent age were made.

The radiocarbon dates of the marine shells were used in dating relative sea-level changes. The age and altitude of the shells could not, however, directly be used in determining former positions of the sealevel. The fossil assemblage and the formation of each marine deposit and its relationship to sea-level had to be taken into account at each studied site. When this was done, the constructed curves of the relative sea-level changes agreed with every shell date. No samples or shell dates seemed likely to have been affected by postdepositional changes in the composition of the shells. On the other hand, some samples from Finnmark in North Norway, showed that no exchange had taken place between carbonate and the environment in which the shells were deposited (Donner, Eronen, and Jungner, 1977). The following examples will give different types of deposits with shells used in the above-mentioned studies, showing the relationship of the deposits to relative sea-level changes. All sites studied can be be referred to one of these types.

\section{Examples of sites}

Sites used as examples are shown in figures 1 and 2 and will be discussed in the same order as the figures.

Lersletten, figure 1A, S of Sydostbugten (Christianshåb), West Greenland (Donner and Jungner, 1975) is an extensive plain of marine clay outside the Fjord Stage moraine formed at about 8000 вр. The surface of the marine clay is at about $50 \mathrm{~m}$ asl, about 5 to $10 \mathrm{~m}$ below the level at which the sea-level stood at the time the marine clay was deposited. Dates of the samples from two localities on the clay surface were almost identical. Shells found in the clay represent the fossil life assemblage of 
marine clay, with, among others, shells of Portlandia arctica. These shells only occur in marine clays in the area of Sydostbugten. Thus, the dates establish the formation of the surface of the marine clay before the regression of sea-level below the surface of the clay plain.

At Orpigsôq, figure 1B, (Christianshåb), West Greenland (Donner and Jungner, 1975), aggradation terrace deposits at the river mouth were formed during relative lowering of sea-level. The oldest age is of shells from the lowermost marine clay, deposited up to an altitude of, at least, $14.1 \mathrm{~m}$. An age of shells from the overlying sand is younger, and the age of Zirphaea crispata, from the terrace gravel reaching $12.9 \mathrm{~m}$ asl and formed near sea-level, is the youngest. Thus, the shell ages from the deposits formed during a regression show the age range of these deposits, with a decrease in age of the shells towards the top. Only the youngest age gives an approximate date for the position of sea level at the formation of the topmost marine gravel. There is also a change in fossil assemblages with, for instance, Portlandia arctica in the lowermost marine clay, and Zirphaea crispata, in the surface gravel.

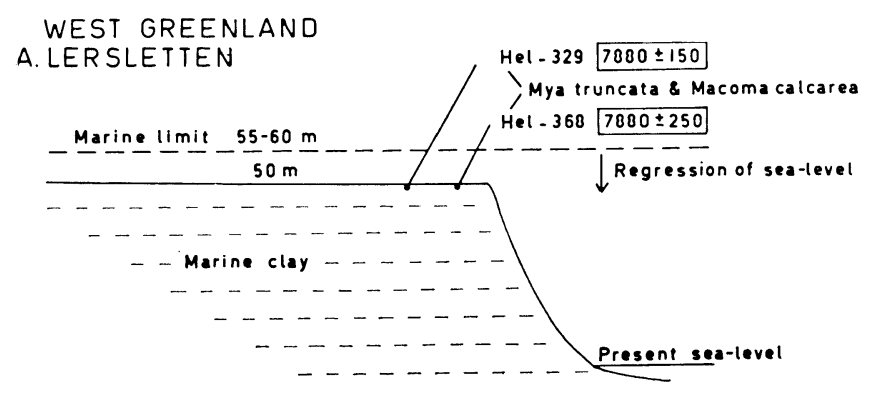

\section{B. ORPIGSÔQ}
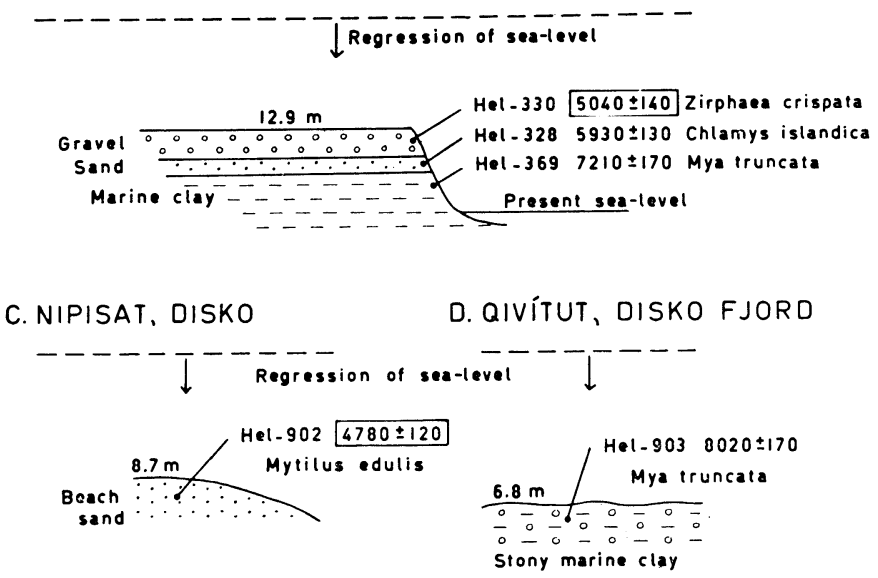

Fig 1. Relationship of deposits and their shells to sea level in some studied sites ia West Greenland. Position of dated shells given for each site. 
At Nipisat, figure 1C, on the West coast of Disko, West Greenland (Donner, 1978), there is beach and formed near sea level during its relative regression, covered with eolian sand. The beach sand only contains shells of Mytilus edulis, contemporaneous with the beach. The age of the shells, therefore, dates the formation of the beach at about sea-level during its regression.

At Qivitut, figure 1D, in Disko Fjord, West Greenland (Donner, 1978), the dated shells were from a bottom sediment of stony marine clay, formed, when compared with other sites, at a water depth of about $55 \mathrm{~m}$, during the relative regression of sea level. The shells mainly represent an indigenous death assemblage from the fjord bottom; therefore, the ages do not date the former position of sea level. The date of Mya truncata from this site, at $6.8 \mathrm{~m}$ asl, is over 3000 years older than the date of Mytilus from the previous site, at $8.7 \mathrm{~m}$ asl, in the same region.

Nûgârssuk, figure 2E, S of Sydostbugten (Christianshåb), West Greenland (Donner and Jungner, 1975), is an example of gravel accumulation formed near sea level during relative regression. Gravel was redeposited

E. NÛGÂRSSUK, WEST GREENLAND

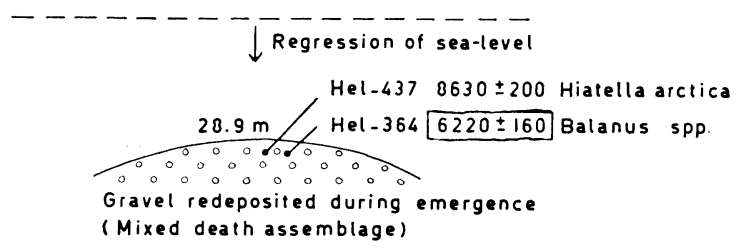

F. NYELVEN, NORTH NORWAY

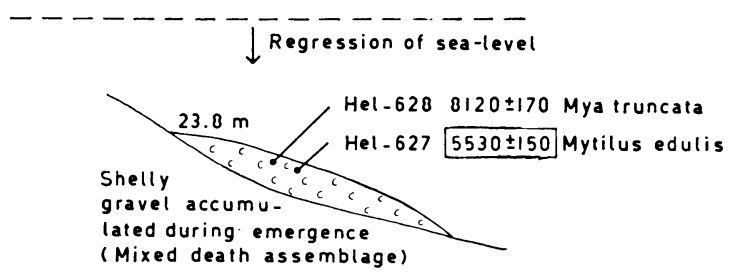

G. SUTTON, DUBLIN BAY, IRELAND

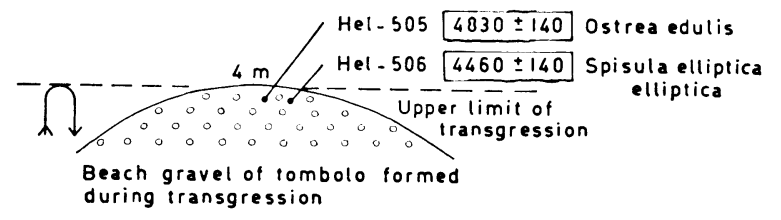

Fig 2. Relationship of deposits and their shells to sea level in some studied sites in West Greenland, North Norway and Ireland. Position of dated shells given for each
site. 
when near sea level and it contains a mixed death assemblage. Shells representing earlier bottom communities, from a time of higher sea level, are mixed with shells from the time that gravel was accumulated near sea level. Therefore, only the younger date of Balanus spp dates the formation of the approximate position of sea level during the regression. When locations like this one, with mixed fossil death assemblages, are used in dating former positions of sea level, several sites are needed for reliable results. Also, shells of fish of the epifauna frequent in the intertidal zone, like Mytilus edulis and Balanus spp, are best suited for dating sea-level changes. Accurate dating requires several dates of different shell species from each deposit. Another difficulty is determining the exact relationship of the deposit to sea-level.

Nyelven, figure 2F, (Nesseby), North Norway (Donner, Eronen, and Jungner, 1977) is a site similar to the one above. A mixed death assemblage occurs on a slope in shelly gravel accumulated during the relative regression of sea level. Here, the age of Mya truncata is 2590 years older than the age of Mytilus edulis, the greatest age difference recorded in all investigated deposits. Mytilus dates, as confirmed with other dates in the same area, the formation of shelly gravel near sea level during its regression. $M y a$ has been incorporated into the gravel from older deposits.

At Sutton, figure 2G, on the north side of Dublin Bay, Ireland, there is a tombolo just below $4 \mathrm{~m}$ asl, which links Howth to the mainland and which was formed during a transgression of sea-level about 5000 BP (Mitchell and Stephens, 1974). Samples collected in 1952 from the gravel at a building site north of the main road from Dublin to Howth gave the two ages in figure 2. In contrast to the two gravel deposits, above, (fig 2E, F), where age differences were considerable, the dates here are close to each other. This is because gravel accumulation at Sutton was formed during the peak of a transgression and shells of the death assemblage are, therefore, contemporaneous with the gravel in which they are found. The gravels were above sea-level before and after the transgression and, thus, cannot contain marine shells from a time before the formation of the tombolo. Shells only accumulated as long as sea level was high. The gravel with shells is similar to the deposits at, for instance, Nûgârssuk, West Greenland, but there is a decisive difference in the relative sea-level changes between the two sites which affects the composition of the marine shells in the deposits.

The relationship between the dated shell samples from the abovementioned sites and sea level, as shown in figures 1 and 2, is also schematically shown in figure 3 . All except the last site are from coasts where there has been a Holocene relative regression as a result of land uplift. In North Norway, a transgression interrupted the regression, but at a higher altitude than at our site (fig 2F). In figure 1, the shells from site A dated the marine limit about 5 to $10 \mathrm{~m}$ above the surface of marine clay on which the shells were found. Of the shells from site $B$, only the youngest age dated the former position of sea-level; the others only dating older terrace deposits. The shells from $\mathrm{C}$ dated the sea-level position, 
whereas at E, only the younger age dated the former position of sea level. The other date gave the age for an older bottom community. At F, the situation was the same. The dated shells from site G, in Ireland, were from a coast where a Holocene transgression reached above present sealevel. Here, the shells dated the peak of the transgression. For accurate determinations of former positions of sea level, a number of sites are required, and when an attempt is made to determine the position of the mean sea level or mean tide level, a detailed study of the deposits from which the shells were collected should also be made. This is particularly important at coasts where the tidal range is great.

\section{CONCLUSIONS}

For the examples above, there is no reason to assume that the ages for the marine shells are not correct. The origin of the shells in the deposits studied varied from site to site and limited the use of dates in the study of relative sea-level changes. The dates provided information on the formation of marine deposits that could not have been obtained from the study of sediments alone. Conclusions about the relationship of shells to sea-level agree with earlier studies by, for instance, Olsson and Blake (1962) of raised beaches in Spitsbergen and later studies in Canada (Barr, 1971; Blake, 1975) and Greenland (Ten Brink, 1974; Kelly, 1973). Our dates confirm earlier results and are not unique.

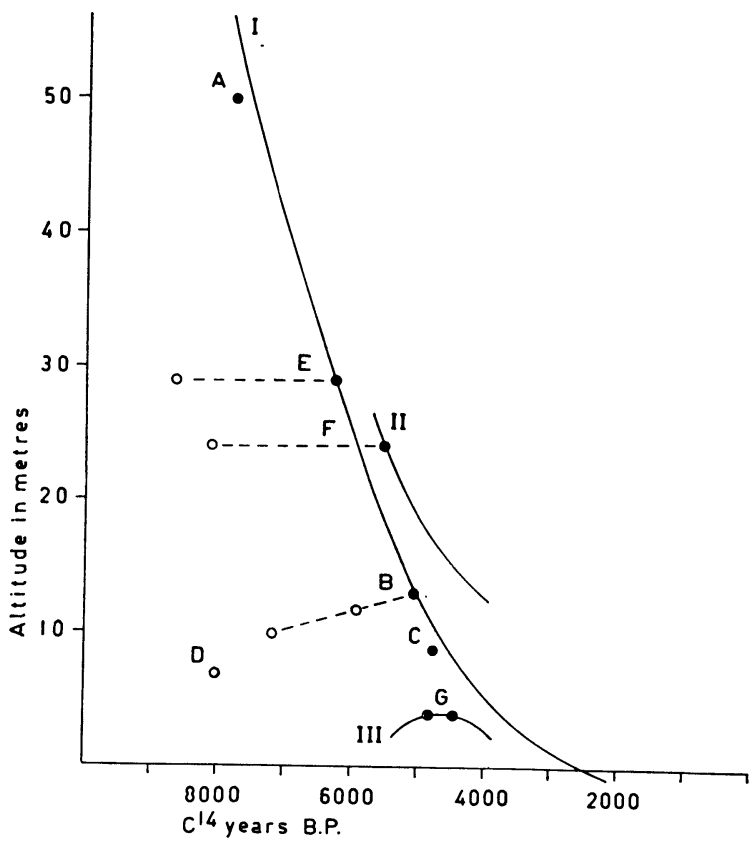

Fig 3. Relationship of dated shells to emergence curves for area south of Disko Bugt, West Greenland (I), Varangerfjord, North Norway (II) and Dublin Bay, Ireland (III). Filled circles represented dates of shells deposited at or near sea level. A-G, sites in figures 1 and 2. 
Radiocarbon ages used in the present paper were given without corrections for isotopic fractionation. The magnitude of these corrections is so small that the corrections would not alter the general pattern illustrated in figures 1 and 2. In East Greenland, apparent ages of bivalves living in East Greenland between 1892 and 1937 was from 0 to ca 200 years when normalized to $\delta^{13} \mathrm{C}=0$ (Tauber and Funder, 1975), and along the coasts of Norway, of shells collected before 1926, was 440 years (Mangerud and Gulliksen, 1975), but for dates normalized to $\delta^{13} \mathrm{C}=$ $-25 \%$. If no corrections based on ${ }^{13} \delta \mathrm{C}$ values are made, as for samples used here, the apparent age is smaller. Whereas apparent ages of dated shells can be determined within the limits of a few hundred years, the existence of other effects producing ages younger or older than true ages have been suggested (see Thommeret, 1976; Aloisi and others, 1978). Jardine (1978), in discussing shell dates from Scotland, concluded that a difference of ca 3000 years between shell samples from the same horizon may have been caused by these effects, one being isotopic replacement in shells after death. Further study of these possible effects, which could seriously hamper the use of shell dates, is, therefore, needed.

\section{REFERENCES}

Aloisi, J C, Monaco, André, Planchais, Nadine, Thommeret, Jean, and Thommeret, Yolande, 1978, The Holocene transgression in the Golfe du Lion, southeastern France: Paleogeographic and paleobotanical evolution: Geog phys Quaternary, v 32, no. 2, p 145-162.

Barr, W, 1971, Postglacial isostatic movement in northeastern Devon Island: A reap praisal: Arctic, v 24, p 249-268.

Blake, Weston, Jr, 1975, Radiocarbon age determinations and postglacial emergence at Cape Storm, southern Ellesmere Island, Arctic Canada: Geografika Annaler, v 57, ser A, $71 \mathrm{p}$

Donner, Joakim, 1978, Holocene history of the west coast of Disko, Central West Greenland: [Geografika Annaler], v 60, ser A, p 63-72.

Donner, Joakim, Eronen, M, and Jungner, Högne, 1977, The dating of the Holocene relative sea level changes in Finnmark, North Norway: Norsk geog Tidsskr, v 31 , no. 4, p 103-128.

Donner, Joakim and Jungner, Högne, 1975, Radiocarbon dating of shells from marine Holocene deposits in the Disko Bugt area, West Greenland: Boreas, v 4, p 25-45. 1979, The use of marine shells in dating land/sea level changes, in Berger, Rainer and Suess, H E, eds, Radiocarbon dating, Internatl radiocarbon conf, 9th, Proc: Berkeley/Los Angeles, Univ California Press, p 397-403.

Jardine, W G, 1978, Radiocarbon ages of raised-beach shells from Oronsay, Inner Hebrides, Scotland: a lesson in interpretation and deduction: Boreas, v 7, p 183-196.

Kelly, M, 1973, Radiocarbon dated shell samples from Nordre Strømfjord West Greenland: Rapp Grønlands geol Unders, v 59, 20 p.

Mangerud, Jan and Gulliksen, Steinar, 1975, Apparent radiocarbon ages of recent marine shells from Norway, Spitsbergen, and Arctic Canada: Quaternary Research, v 5, p 263-273.

Mitchell, G F and Stephens, N, 1974, Is there evidence for a Holocene sea-level higher than that of today on the coasts of Ireland?: Coll Internatl CNRS, v 219, p 115-125.

Olsson, I U and Blake, Weston, Jr, 1962, Problems of radiocarbon dating of raised beaches, based on experience in Spitsbergen: Norsk geog Tidsskr, v 18, no. 1-2, $18 \mathrm{p}$.

Tauber, Henrik and Funder, Svend, $1975,{ }^{14} \mathrm{C}$ content of recent molluscs from Scoresby Sund, central East Greenland: Rapp Gronlands geol Unders, v 75, p 95-99.

Ten Brink, N W, 1974, Glacio-isostacy: new data from West-Greenland and geophysical implications: Geol Soc America Bull, v 85, p 219-228.

Thommeret, Jean, 1976, Difficultés d'interprétation des dates ${ }^{14} \mathrm{C}$ mesurées à partir de coquilles marines: Coll internatl CNRS, Cong internatl Sci préhist protohist, 9 th, Nice, p 160-169. 